\title{
Feasibility Study of Monsoon Effect on Wave Power for Wave Energy Converter in Sabah, Malaysia
}

\author{
Nur Syafiqa Aifa Shahrom, M.N. Azzeri, Mohd Shukri Yusop, \\ Mohd Norsyarizad Razali, Mohd Najib Bin Abdul Ghani \\ Yolhamid, Ainul Rahman, Sarah Isnan, Afiqah Rosly, Mohd \\ Arif Ahmad
}

This paper presents a research to determine the effects of the Northeast Monsoon (NEM) and the Southwest Monsoon (SWM) on wave power along the coastal area of Mandi Darah Island, Sabah. This study identified the daily data of wave height and wave period for 6 months from June to December 2018. The following period was chosen because it consisted of two monsoon seasons in Sabah. The data obtained from the Acoustic Doppler Current Profiler (ADCP) were thoroughly analyzed to estimate the wave height and the wave period to identify the wave power at Mandi Darah Island. The wave heights ranged from $0.01 \mathrm{~m}$ to $0.47 \mathrm{~m}$ while the wave periods ranged from 1.0

\section{KEY WORDS}

$\sim$ Wave energy converter

$\sim$ Wave power

$\sim$ Wave height

$\sim$ Wave period

$\sim$ Mandi Darah Island

Universiti Pertahanan Nasional Malaysia, Kuala Lumpur, Malaysia e-mail: azzeri@upnm.edu.my

doi: 10.7225/toms.v10.n02.w05

This work is licensed under (cc) BY

Received on:09.06.2021/Revised on: 15.07.2021/Accepted on: 21.07.2021/Published online: 29.07 .2021 $\mathrm{s}$ to $8.6 \mathrm{~s}$. The wave height range during the NEM was higher by

$0.12 \mathrm{~m}$ than SWM, while the difference of wave period was significantly higher by $2.17 \mathrm{~s}$ during the NEM. The maximum wave power recorded at Mandi Darah Island was $1.57 \mathrm{~kW} / \mathrm{m}$ throughout the period. During NEM, the wave power was significantly higher than during SWM, by $0.70 \mathrm{~kW} / \mathrm{m}$. These findings led to determining the wave energy type converter that suits the wave conditions at the Mandi Darah Island coastal area.

\section{INTRODUCTION}

Since 2000 Malaysia has established the Eighth Malaysia Plan, which included renewable energy as a core element in the country's fuel policy, along with hydro, coal, gas and oil (Kardooni et al., 2018). Renewable energy has become important (Silva et al., 2015) and has a huge involvement to reduce the cost of fossils fuel and to save the environmental problems (Veigas et al., 2014). Ocean energy includes three essential components, i.e. wind, waves, and currents, which can create energy conversion. Wave energy is more predictable, has higher energetic density (Muzathik et al., 2010b; Neill \& Hashemi, 2013) and is widely known as one of the most efficient alternative energy sources to replace renewable energy sources (Yaakob et al., 2016).

Seas and oceans are motion energy major sources, which include waves, tides, currents, thermal and salinity energies. Wave energy has been established as a renewable energy of 
wave energy converters (WECs) design since 1855 (Zanous et al., 2019). WECs have the advantage of operating under particular wave - climate conditions (wave height and wave-period) and their generation depends not only on the available resources, which are the coupling factor between the chamber and the air turbine, but also on the characteristics of the sea states (tidal level) (Veigas et al., 2014; López, I. \& Iglesias, G., 2014). According to the study, in order to decide the optimum positions for a wave power plant, changes in WEC power spectrum under wave conditions should be considered in compliance with the available energy resource. The majority of wave energy potential calculations are limited to the estimation of wave energy potential in a given coastal region and the assessment of those areas with the largest amount of energy. The calculation is done by using wave power measurement.

The frequency of wave energy flow per unit of wave-crest length (wave power) can be calculated at any depth of water using the formula given (Foteinis et al., 2017; Vögler \& Morrison, 2013). New calculation methodologies need to be built on both of these criteria in order to identify more accurate places and more wave-energy opportunities.

Many studies of wave power for energy conversion evaluation at various locations have been investigated over decades through established methodologies. Study of wave power potential of Malaysia (Mirzaei et al., 2014; Muzathik et al., 2010a; Samrat et al., 2014; Tan et al., 2017; Yaakob et al., 2006), Terengganu (Jaswar et al., 2014; Muzathik et al., 2010b) and Sabah (Ejria et al., 2010) can be found in the related literatures. There are different characters and energy densities depending on locations and weather conditions in different places. The design of nearshore wave energy converter generally consists of parameters of wave characteristics. The parameters of wave characteristics considered in WEC design were wave height and wave period. Knowledge about the behavior of the ocean waves is important in designing the suitable wave energy converter because the wave characteristics in deep water and shallow water are different (Tan et al., 2017)

Therefore, a significant effort is being made to explore the wave power potential of the coastal regions of Mandi Darah Island, Sabah in order to provide insight into the appropriate location for the selection and installation of WEC systems. The objective of this study is to determine the effects of NEM and SWM to the wave power along the coastal area of Mandi Darah Island. The wave data collected is going to be used for a proposal of WEC deployment to suit the wave regime in the coastal area of Mandi Darah Island.

\section{GEOGRAPHICAL LOCATION}

Mandi Darah Island is a small island located in Kudat Division (Monaliza \& Samsur, 2011), which is the northern area of Borneo Island and bounded by latitude $6^{\circ} 55^{\prime} 44.52^{\prime \prime} \mathrm{N}$ and longitude $117^{\circ} 20^{\prime} 2.37^{\prime \prime} \mathrm{E}$ (Figure 1). As shown in Figure 2, synoptic charts from Malaysian Meteorology Department (MMD) utilizing National Centers for Environmental Prediction (NCEP) Reanalysis of Mandi Darah Island that depict Northeast Monsoon (NEM) and Southwest Monsoon (SWM). Mandi Darah Island location in synoptic maps also shown in Figure 2. Mandi Darah Island is subject to direct wind blow, particularly during the Northeast Monsoon (NEM), with occasional storms. This is because Mandi Darah Island is surrounded by Sulu Sea (Figure 3). The Sulu Sea is an enclosed sea, like the Mediterranean Sea, divided by a chain of islands from the surrounding waters: Borneo Island in the southwest, Palawan in the west, Busuanga and Mindoro in the north, Panay, Negros and Mindanao in the east, and the Sulu Archipelago in the southeast (Ejria et al., 2010).

The permanent residence on Mandi Darah Island is scarce, with about 35 houses constructed on the beach, where between 40 and 75 people abide. Mandi Darah Island was chosen as study area because due to the lack of infrastructure, wave energy is used to supply electricity to the villages as well as to the army camp situated on Mandi Darah Island.

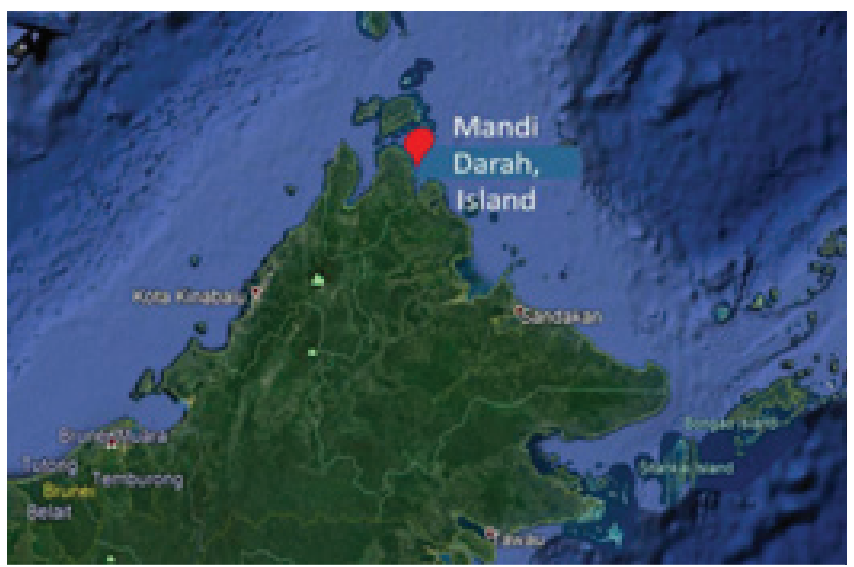

Figure 1.

Location map of Mandi Darah Island in the northern part of Sabah 


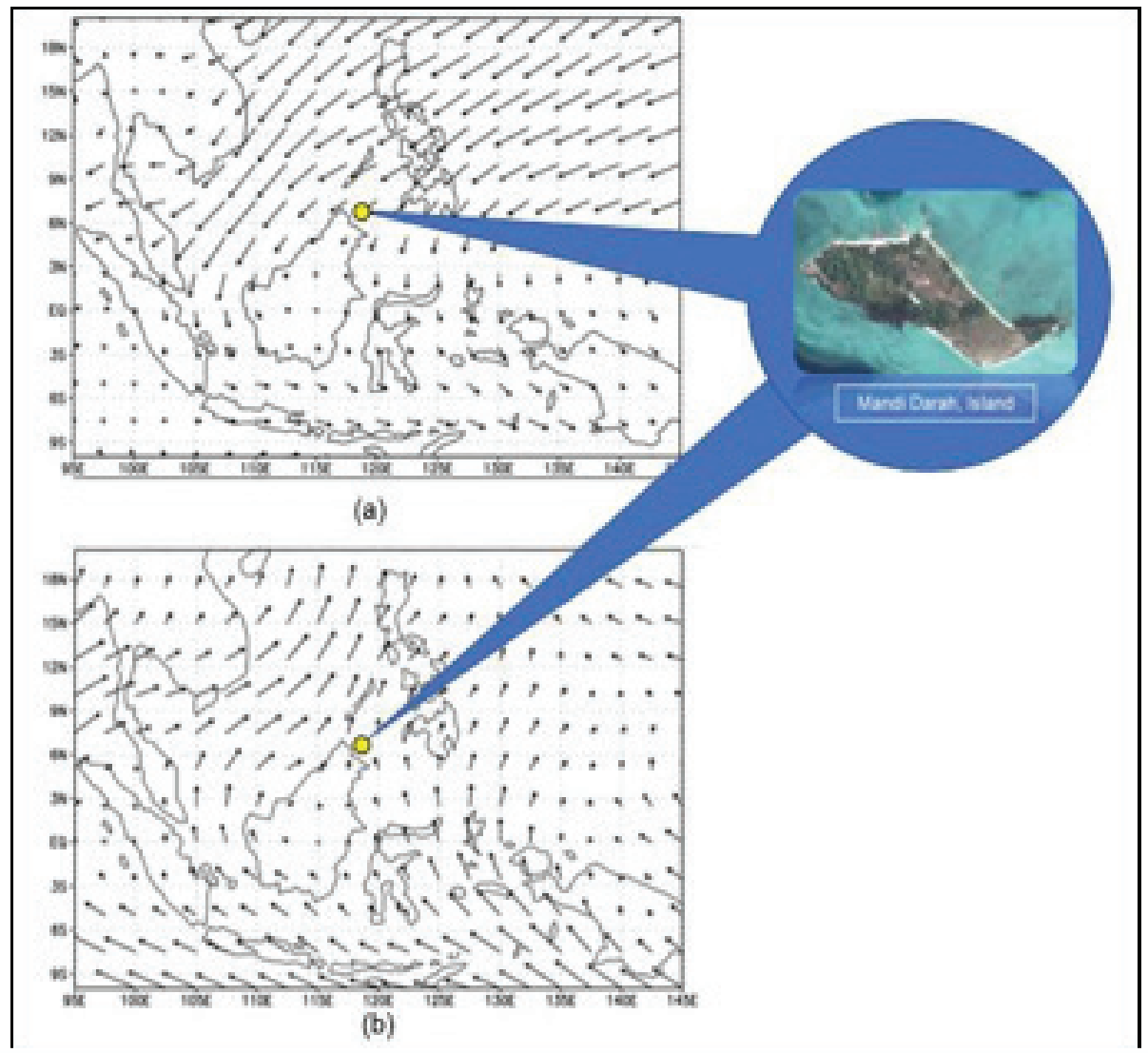

Figure 2.

Wind direction from the NCEP Reanalysis: (a) NEM and (b) SWM.

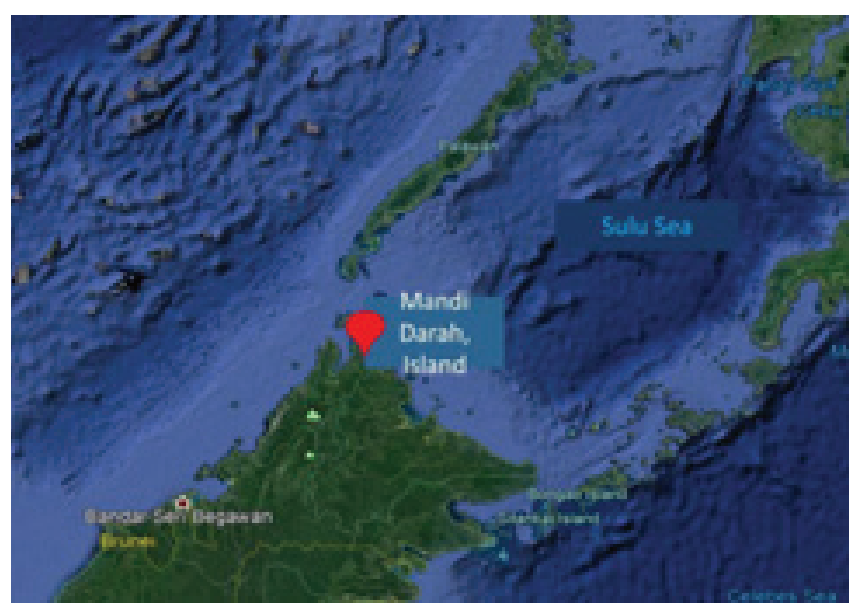

Figure 3.

Mandi Darah Island located in the Sulu Sea.

\section{WAVE MEASUREMENT}

This study was based on the six-hour data collected at wave measurements stations, covering the period from the Acoustic Doppler Current Profiler (ADCP). The ADCP is a hydroacoustic current meter similar to a sonar, which measures water velocity and direction over a range of depths, simultaneously measuring bathymetry. Based on Comprehensive Manual for ADCP (2018), an ADCP instrument transmits a short, constant-frequency sound pulse ("ping") into the water, then listens for the echo and measures the change in the pitch or frequency of the echo. The frequency difference between transmitted and received pulses is proportional to water velocity.

The ADCP measures water velocity by emitting a sound pulse from microscopic suspended particles that float passively in the water and are supposed to travel at the same speed as water - the velocity of the particle recorded equals the velocity of the water surrounding the particle. 
area were lower from June to October and higher from November to December. The influence of the northeast and the southwest monsoons is the explanation for these phenomena. During the monsoon season, more energy can be supplied to the study area due to more storms and winds to the coast. The monthly average wave height obtained varied from $0.07 \mathrm{~m}$ to $0.13 \mathrm{~m}$; thus, the recorded data show most of the wave heights occurring within $0.05 \mathrm{~m}$ to $0.10 \mathrm{~m}$.

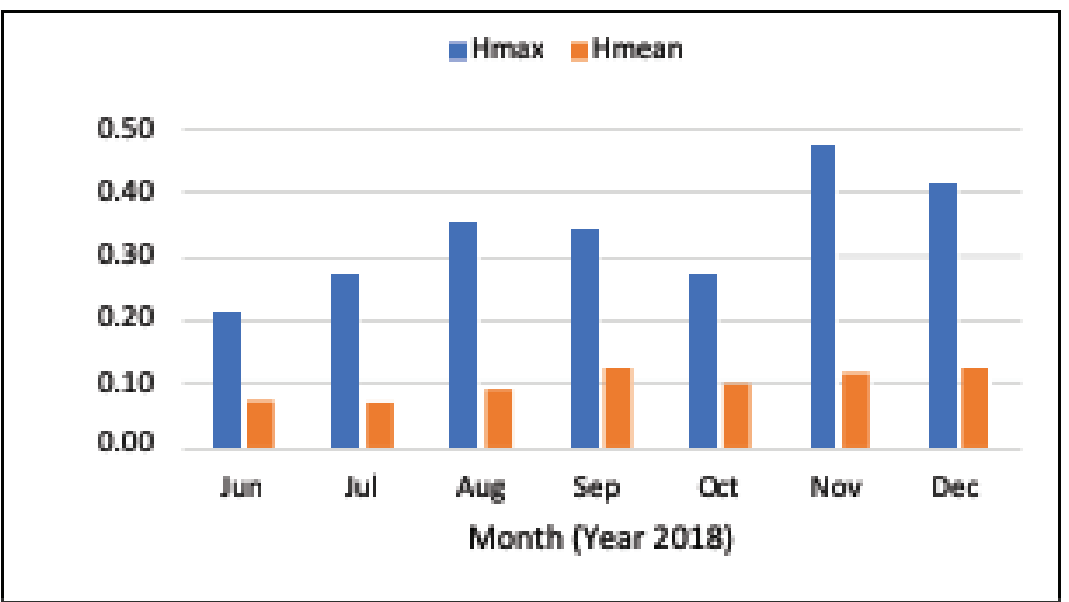

Figure 5.

The maximum wave height $\left(\mathrm{H}_{\max }\right)$ and mean wave height $\left(\mathrm{H}_{\text {mean }}\right)$ recorded at Mandi Darah Island.

As shown in Figure 5, the maximum wave height recorded in Mandi Darah Island was $0.47 \mathrm{~m}$. The data indicated that the wave height in the coastal area was relatively low compared to the wave height in the offshore area. The mean wave height was $0.10 \mathrm{~m}$ and the mean wave period was $1.97 \mathrm{~s}$ on Mandi Darah Island, Sabah, Malaysia.

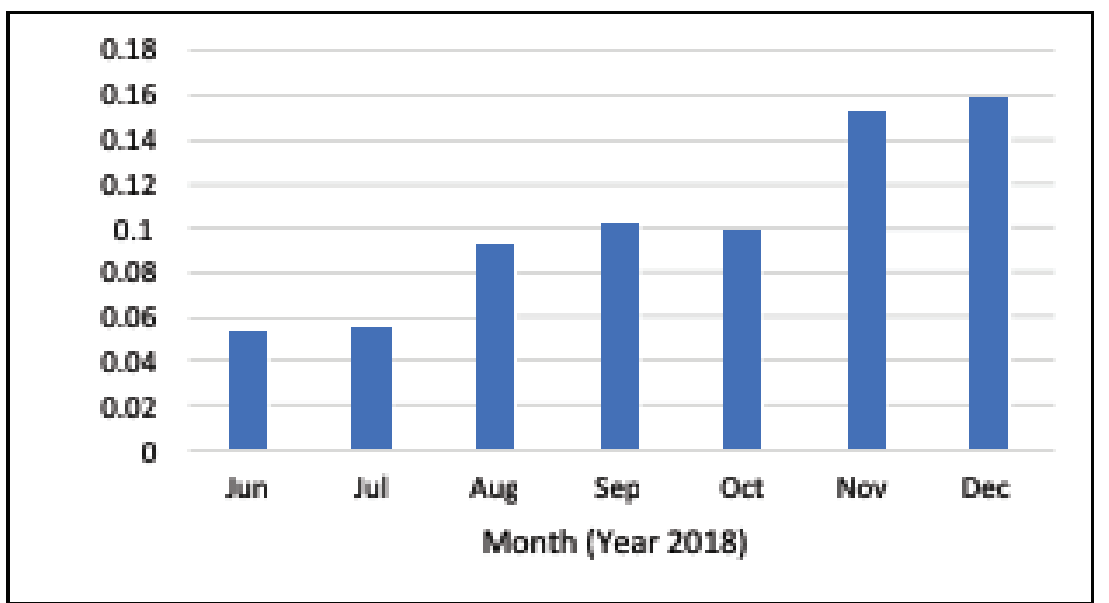

Figure 6.

Monthly average wave power $(\mathrm{kW} / \mathrm{m})$.

The study revealed that the annual average wave power was $0.11 \mathrm{~kW} / \mathrm{m}$. In the calculation of wave power on the Mandi Darah Island shore, for the average values of $\mathrm{H}_{\mathrm{m} 0}=0.10 \mathrm{~m}$ and $T_{p}=1.97 \mathrm{~s}$, one may consider it based on the available wave power. A bar graph has been plotted as in Figure 7 to better visualize the monthly variation of wave power potential. The monthly average wave power varied between $0.05 \mathrm{~kW} / \mathrm{m}$ and $0.16 \mathrm{~kW} / \mathrm{m}$. It can also be noted that, in general, the average monthly wave power at the beginning of June and July was lower than at the end of the year. 

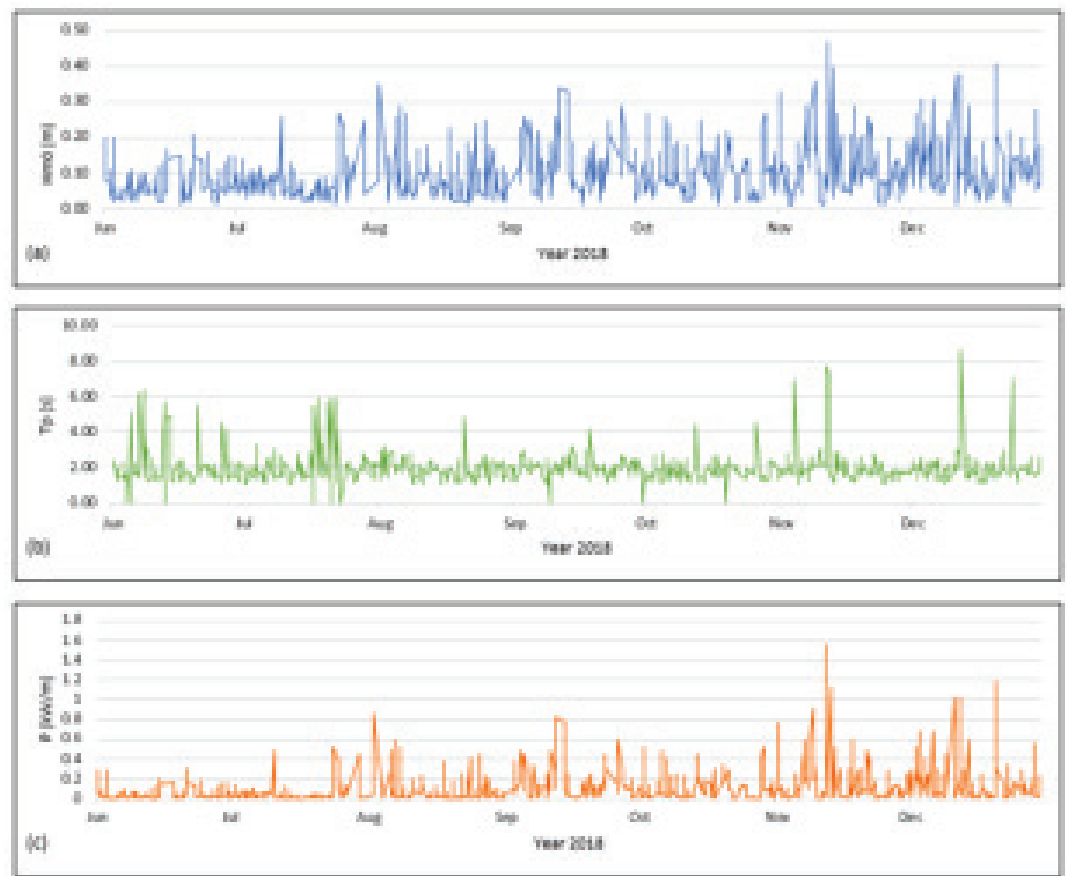

Figure 7.

Annual wave characteristics: (a) significant wave height $(\mathrm{m})$, (b) peak period (s) and (c) wave power (kW/m).

The wave energy intensity differed seasonally, with the maximum energy density occurring during the northeast monsoon, with more storms and waves, while lower energy density occurred during the southwest monsoon. The annual wave characteristics of $\mathrm{H}_{m 0^{\prime}} \mathrm{T}_{\mathrm{p}}$ and wave power, which were calculated using Equation 1 are presented in Figure 8. It is clearly stated that Mandi Darah Island wave climates can be divided into three seasons: the first season covering the period from November to December; the second season covering the period from August to October; the third season covering the period from June to July. The third season presents the calm season in the study area which was from June to December 2018.

Figure 8 indicates that Mandi Darah Island had the most maximum values of $\mathrm{H}_{m 0^{\prime}} T_{p}$ and wave power during the NEM which was in November until December 2018. This is because wind from the NEM directly flowed through Mandi Darah Island from Sulu Sea. The wind speed during NEM was estimated achieve maximum value at $6.68 \mathrm{~m} / \mathrm{s}$. Wind data were obtained from MMD of NCEP Reanalysis.

The main directions of the wind during NEM were mostly coming from east. The wind speed for NEM accounts for more than $50 \%$ throughout the study period (Figure 9). However, during SWM in June to September period, Mandi Darah Island faced wind from the South China Sea and had low values of $\mathrm{H}_{\mathrm{mo}}$ $\mathrm{T}_{\mathrm{p}}$ and wave power. This was related to the wind speed for SWM, which constitutes 25\%. During SWM, the wind directions for the study period are from the West, followed by those from the Southwest (Figure 10).

The annual variation of wave characteristics is an essential parameter in WEC design. According to the wave conditions at Mandi Darah Island, the possibilities to utilize wave power to Mandi Darah Island shore was low because the wave height noted was lower than $0.5 \mathrm{~m}$. It was lower than the requirement for the device to work (Najmuddin et al., 2021). 


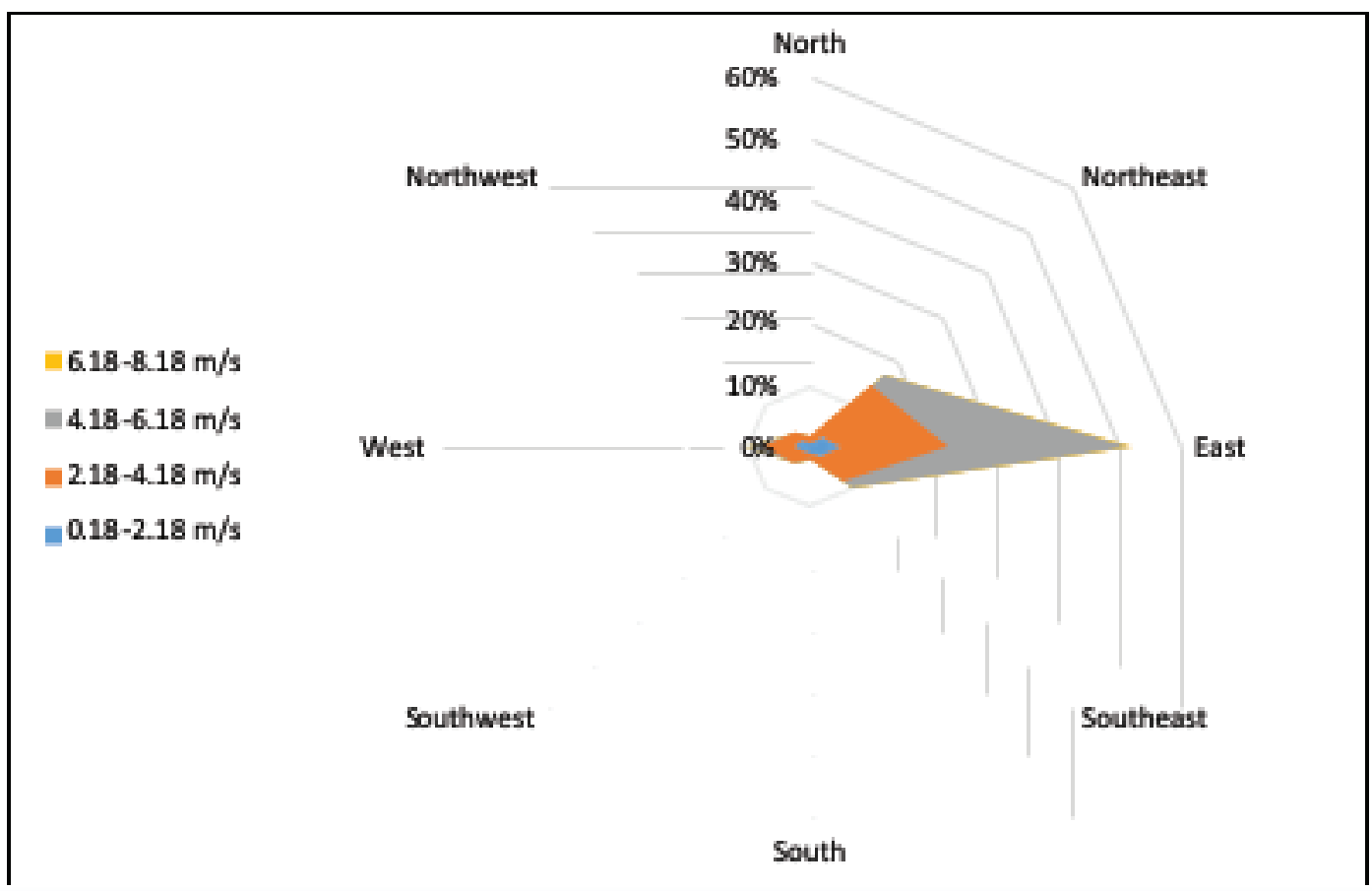

Figure 8.

Wind rose during NEM.

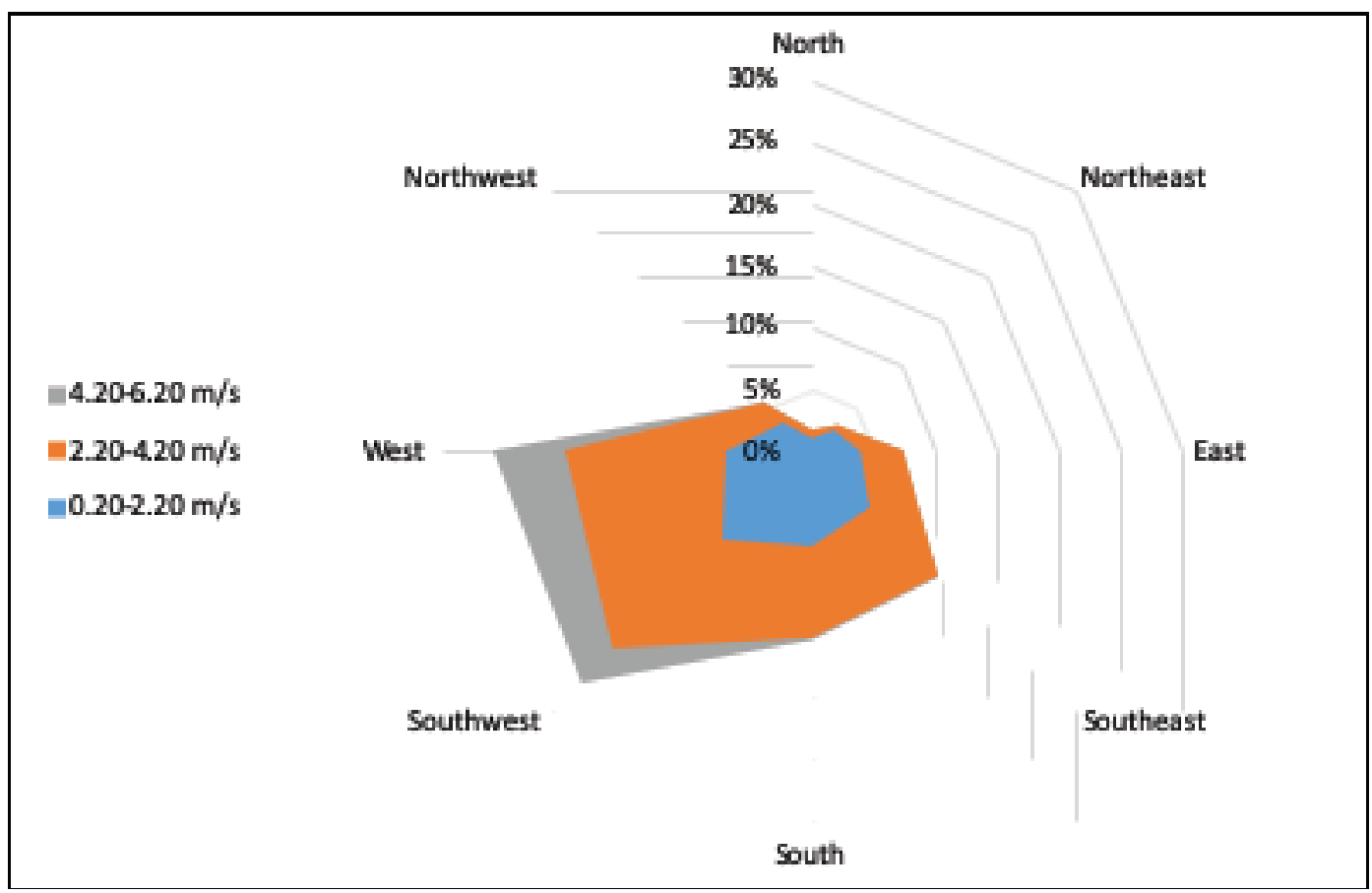

Figure 9.

Wind rose during SWM. 


\section{CONCLUSION}

In conclusion, the study reviewed the wave characteristics of Mandi Darah Island. A wide range of parameters have to be tested and analyzed to determine the effects of the Northeast Monsoon (NEM) and the Southwest Monsoon (SWM) on the wave power along the coastal area of Mandi Darah Island. This study identified the monthly wave height and wave period data for 6 months, using the Acoustic Doppler Current Profiler (ADCP) equipment. All the data was thoroughly analyzed to estimate the highest probability wave height and wave period in the study area. The range of wave heights in the coastal waters surrounding Mandi Darah Island was found out to be $0.01 \mathrm{~m}$ to $0.47 \mathrm{~m}$, and the wave periods ranging from $1.0 \mathrm{~s}$ to $8.60 \mathrm{~s}$. It was found out that wave height and wave period during NEM was higher by $0.12 \mathrm{~m}$ and $2.17 \mathrm{~s}$ than that during the SWM. The maximum wave energy flow per unit of wave-crest length (wave power) at Mandi Darah Island was $1.57 \mathrm{~kW} / \mathrm{m}$ throughout the period. During NEM, the wave power was significantly higher by $0.70 \mathrm{~kW} / \mathrm{m}$ than the SWM. The wave power available was considered small and WEC cannot be fully utilized. Although the available energy was considered to be limited and cannot be completely exploited, special devices can be built in future using a relatively lower wave-height in Mandi Darah Island in order to convert the wave energy more effectively.

\section{ACKNOWLEDGEMENT}

We would like to thank Geohydrocean Services Sdn. Bhd. for providing with the ADCP wave measurements and for instruments deployment. The authors also wish to thank the Research and Innovation Centre, UPNM, for their financial support of this study through the Grant project (KeTTHA) Scientific Marine Research Group number UPNM/2018/AAIBEOKETTHA/TK/I/P2.

\section{REFERENCES}

Comprehensive Manual for ADCP., 2018. Available at: https://support.nortekgroup. com/hc/en-us/articles/360029839331-The-Comprehensive-Manual-ADCP.

Saleh, 2010. Wave Characteristics in Sabah Waters. American Journal of Environmental Sciences, 6(3), pp.219-223. Available at:

http://dx.doi.org/10.3844/ajessp.2010.219.223.

Foteinis, S. et al., 2017. A comparative analysis of wave power in the nearshore by WAM estimates and in-situ (AWAC) measurements. The case study of Varkiza, Athens, Greece. Energy, 138, pp.500-508. Available at: http://dx.doi.org/10.1016/j.energy.2017.07.061.

Jaswar, J. et al., 2014. Estimation of Electrical-Wave Power in Merang Shore, Terengganu, Malaysia. Jurnal Teknologi, 66(2). Available at: http://dx.doi.org/10.11113/jt.v66.2476.

Kardooni, R. et al., 2018. Public opinion on renewable energy technologies and climate change in Peninsular Malaysia. Renewable Energy, 116, pp.659-668.
Available at:

http://dx.doi.org/10.1016/j.renene.2017.09.073

López, I. \& Iglesias, G., 2014. Efficiency of OWC wave energy converters: A virtual laboratory. Applied Ocean Research, 44, pp.63-70. Available at: http://dx.doi.org/10.1016/j.apor.2013.11.001

Mirzaei, A., Tangang, F. \& Juneng, L., 2014. Wave energy potential along the east coast of Peninsular Malaysia. Energy, 68, pp.722-734. Available at: http://dx.doi.org/10.1016/j.energy.2014.02.005.

Monaliza, M.D., \& Samsur, M., 2011. Toxicity and toxin properties study of puffer fish collected from Sabah waters, Health and the Environment Journal, 2(1), pp. 14-17.

Muzathik, A.M., et al., 2010a. Wave energy potential of Peninsular Malaysia, ARPN Journal of Engineering \& Applied Sciences, 5(7), pp. 11-23.

Muzathik, A.M., et al., 2010b. Ocean wave energy along Terengganu coast of Malaysia in The 2nd International Conference on Plant Equipment and Reliability (ICPER 2010) Proceedings, Kuala Lumpur, 15-17 June 2010, Universiti Teknologi Petronas, Malaysia.

Najmuddin, W.S.W.A. et al., 2020. Feasibility Study of Wave Energy Converter Using Compressed Air to Generate Electricity. Advances in Mechatronics, Manufacturing, and Mechanical Engineering, pp.147-153. Available at:

http://dx.doi.org/10.1007/978-981-15-7309-5_15.

Neill, S.P. \& Hashemi, M.R., 2013. Wave power variability over the northwest European shelf seas. Applied Energy, 106, pp.31-46. Available at: http://dx.doi.org/10.1016/j.apenergy.2013.01.026

Rameswar, B., 1978. Dynamics of Marine Vehicles. John Wiley \& Sons, Inc.

Samrat, N.H. et al., 2014. Prospect of wave energy in Malaysia. 2014 IEEE 8th International Power Engineering and Optimization Conference (PEOCO2014). Available at:

http://dx.doi.org/10.1109/peoco.2014.6814412.

Silva, D. et al., 2015. High resolution local wave energy modelling in the Iberian Peninsula. Energy, 91, pp.1099-1112. Available at: http://dx.doi.org/10.1016/j.energy.2015.08.067.

Tan, W.C., Chan, K.W. \& Ooi, H., 2017. Study of the potential of wave energy in Malaysia. Available at:

http://dx.doi.org/10.1063/1.4993401.

Veigas, M., López, M. \& Iglesias, G., 2014. Assessing the optimal location for a shoreline wave energy converter. Applied Energy, 132, pp.404-411. Available at: http://dx.doi.org/10.1016/j.apenergy.2014.07.067.

Vögler, A. \& Morrison, J., 2013. Assessment of the grid capacity sharing potential for wave and wind energy conversion systems in the Outer Hebrides of Scotland in The European Wave and Tidal Energy Conference (EWTEC 2013), Aalborg, Denmark, 2-5 September 2013.

Yaakob, O. et al., 2016. Satellite-based wave data and wave energy resource assessment for South China Sea. Renewable Energy, 88, pp.359-371. Available at: http://dx.doi.org/10.1016/j.renene.2015.11.039.

Yaakob, O., Tengku Ab Rashid, T.M.A. \& Mukti, M.A.A., 2006. Prospects for ocean energy in Malaysia in International Conference on Energy and Environment 2006 (ICEE 2006). Bangi, Malaysia, 28-30 August 2006, pp. 62-68.

Zanous, S.P. et al., 2019. Feasibility study of wave energy harvesting along the southern coast and islands of Iran. Renewable Energy, 135, pp.502-514. Available at: http://dx.doi.org/10.1016/j.renene.2018.12.027. 